\title{
Enterotoxigenic potential of Staphylococcus aureus isolated from Artisan Minas cheese from the Serra da Canastra - MG, Brazil
} Milene Therezinha das DORES ${ }^{1 *}$, Ricardo Souza DIAS ${ }^{2}$, Edna Froeder ARCURI ${ }^{3}$, Juliana Escarião da NOBREGA ${ }^{1}$, Célia Lucia de Luces Fortes FERREIRA ${ }^{1}$

\begin{abstract}
This study aimed to evaluate the presence of enterotoxigenic S. aureus in the endogenous starter and in Artisan Minas cheeses from the Serra da Canastra. Sixteen samples of endogenous starters and cheese were collected during the rainy and dry seasons. The isolation and enumeration of $S$. aureus were performed using the Petrifilm ${ }^{\mathrm{TM}}$-Rapid $S$. aureus Plate Count method. The presence of enterotoxin in the cheese samples was analyzed by the Optimal Sensitivity Plate (OSP) method and the ELFA-VIDAS ${ }^{\oplus}$-Staph enterotoxin-II assay. S. aureus strains were tested for their ability to produce enterotoxins using the Optimal Sensitivity Plate (OSP) method and the polymerase chain reaction (PCR) assay for the classical enterotoxin genes. The Optimal Sensitivity Plate (OSP) method data showed that staphylococcal enterotoxin A (SEA) was detected in 75\% of the cheese samples, but no toxin was detected with the ELFA-VIDAS method. It was found that $12.5 \%$ of the isolated strains produced staphylococcal enterotoxin A (SEA) and staphylococcal enterotoxin C (SEC). When using the the polymerase chain reaction (PCR) assay, only one isolate was found to harbor an enterotoxin gene, contrary our expectations. However, discrepancies between the immunological and molecular assays are not uncommon. Despite the fact that most isolates did not produce classical enterotoxins, high $S$. aureus counts in the cheese samples causes concern since there is a risk of the presence of non-classical enterotoxins.
\end{abstract}

Keywords: Staphylococcal enterotoxins; Artisan cheese; Staphylococcus aureus.

\section{Introduction}

The Artisan Minas cheese from the Serra da Canastra is one of the oldest and most traditional cheeses produced in Brazil. It is an income-generating activity for a large number of smallscale farmers. Its centenary production consists of inoculating endogenous starter cultures, which are collected from previous batches, into freshly collected raw milk in order to influence the fermentation process. The main genera of the endogenous starter are Lactobacillus, Lactococcus and Streptococcus with counts of approximately $8 \log$ cfu.mL $\mathrm{mL}^{-1}$ (BORELLI et al., 2006; NOBREGA; FERREIRA; DORES, 2008).

Food contamination by $S$. aureus and the possibility of staphylococcal toxin production represent a potential risk to public health. Staphylococcal enterotoxins belong to a family of twenty thermostable, pepsin-resistant, single chain exoproteins which range in molecular weight from 25,000 to $29,600 \mathrm{Da}$ (SEO; BOHACH, 2010). Most staphylococcal strains are able to produce one or more enterotoxins, which are the cause of the gastrointestinal symptoms including vomiting and diarrhea (MARTIN; MYERS; LANDOLO, 2001; HENNEKINNE; DE BUYSER; DRAGACCI, 2011). Among the foods involved in staphylococcal intoxication outbreaks, raw milk and cheeses are the most common from the dairy category, and S. aureus is the most commonly found etiologic agent in epidemiological investigations (DE BUYSER et al., 2001; IKEDA et al., 2005).
Microbiological determinations in Artisan cheeses have frequently indicated the presence of $S$. aureus at levels above those permitted by law (PINTO; MARTINS; FERREIRA, 2004; BRANT; FONSECA; SILVA, 2007; BORELLI et al., 2006; MARTINS, 2006; DORES, 2007). On the other hand, there are few reports or notifications of staphylococcal food poisoning associated with the consumption of these products since reports of staphylococcal food poisoning are not considered compulsory in Brazil. Therefore the actual level of contamination with Staphylococcus in artisan cheeses is unknown (STAMFORD et al., 2006).

Dores (2007) analyzed the minimum ripening period necessary to ensure safety in Artisan Minas cheese from the Serra da Canastra and found that the counts of $S$. aureus were above those permitted by the Brazilian legislation (2.0 $\log$ cfu. $\mathrm{g}^{-1}$ ) during longer periods of time thus defining the minimum ripening period necessary to guarantee food safety (State Law N. 14,185, January 2002 (amended by decree N. 44,864, August 2008). The author verified the presence of this microorganism after 64 -days of ripening at $10^{\circ} \mathrm{C}$ and estimated that at least 84 days of ripening at this same temperature would be necessary to reduce the counts to acceptable levels. Similar results were found by Martins (2006) when monitoring the ripening of Artisan Serro cheeses.

\footnotetext{
Received 28/5/2012

Accepted 13/2/2013 (005688)

1 Universidade Federal de Viçosa - UFV, BR 354, Km 310, CP 22, Campus Rio Paranaíba, CEP 38810-000, Rio Paranaíba, MG, Brasil, e-mail: milene.dores@ufv.br

${ }^{2}$ Fundação Ezequiel Dias - FUNED, CEP 30510-010, Belo Horizonte, MG, Brasil

${ }^{3}$ Embrapa Gado de leite, CEP 36038-330, Juiz de Fora, MG, Brasil

${ }^{*}$ Corresponding author
} 
The presence of $S$. aureus is common in Artisan Minas cheese, and the lack of reports of outbreak of staphylococcal food poisoning associated with its consumption prompted us to investigate the enterotoxigenic potential of $S$. aureus strains to contaminate the endogenous starter and Artisan cheeses from the Serra da Canastra - MG.

\section{Materials and methods}

Samples of Artisan Minas cheese and of endogenous starter were collected from eight different farms during two periods of the year: the rainy season, between December and January, and the dry season, between September and August. A total of 16 samples of cheese and 16 samples of endogenous starter were collected. The samples were stored and transported under refrigeration $\left(\sim 10^{\circ} \mathrm{C}\right)$ until analysis. Microbiological analyses and enterotoxin determination were performed within a 48 hour period after sampling.

The isolation and enumeration of $S$. aureus were performed using the Petrifilm ${ }^{\mathrm{TM}}$-Rapid S. aureus Plate Count method (3M Center, St. Paul, USA) according to the manufacturer's recommendations. The data of counts of $S$. aureus in the cheese and endogenous starter samples were submitted to analysis of variance (ANOVA) F test at a 5\% probability.

One hundred representative isolates were selected, which were subjected to biochemical analyses with the API Staph (BioMérieux SA, Marcy-l'Etoile, France) system for identification of staphylococci and micrococci. S. aureus strains that showed different reaction profiles were selected, totaling 44 isolates.

The presence of staphylococcal enterotoxin in the cheese samples was analyzed by the OSP method for the Staphylococcal enterotoxins SEA, SEB, SEC, and SED (ROBBINS; GOULD; BERGDOLL, 1974) and by the Enzyme Linked Fluorescent Assay (ELFA - VIDAS ${ }^{\circledast}$ Staph enterotoxin II, BioMérieux SA, Marcy-l'Etoile, France) for the enterotoxins SEA, SEB, SEC, SEC1, SEC2, SEC3, SED, and SEE. Both assays were performed at the Laboratory of Staphylococcal Enterotoxins, FUNED (Belo Horizonte, MG, Brazil).

The 44 S. aureus isolated strains were induced in vitro in order to produce enterotoxins. The analysis of in vitro enterotoxin production was carried out by the OSP method for the detection of SEA, SEB, SEC, and SED. The detection of enterotoxin-encoding genes was performed using a PCR protocol for the sea, seb, sec, sed, and, see genes. Cellular DNA was extracted as described by Hesselbarth and Schwarz (1995). The oligonucleotides were described by Rosec and Gigaud (2002) and are listed in Table 1. The reactions were performed under previously described conditions (ROSEC; GIGAUD, 2002) with some changes as proposed by Arcuri et al. (2004).

For each PCR reaction, a positive and a negative control were used. The strains of $S$. aureus from the American Type Culture Collection (ATCC) S. aureus ATCC 13565 (sea), S. aureus ATCC 14458 (seb), S. aureus ATCC 19095 (sec), S. aureus ATCC 23235 (sed), and S. aureus ATCC 27664 (see) were used as positive control.

\section{Results}

The $S$. aureus counts in the samples of Artisan Minas cheese from the Serra da Canastra - MG - Brazil ranged from 3.48 to $5.88 \mathrm{log}$ cfu. $\mathrm{g}^{-1}$ during the rainy season and from 3.11 to 4.60 log cfu.g ${ }^{-1}$ during the dry season (Table 2). The statistical analysis showed no significant difference between the data from the two seasons $(\mathrm{P}<0.05)$. Counts from all samples were higher than $2.0 \log$ cfu. $\mathrm{g}^{-1}$, which is the maximum limit allowed by the Brazilian legislation. Approximately one third of the Canastra cheese samples were within the ranges indicated in the literature $\left(>5 \log\right.$ cfu. $\left.\mathrm{g}^{-1}\right)$ as those likely to produce enterotoxins (IKEDA et al., 2005; JØRGENSEN et al., 2005; ZWEIFEL et al., 2006).

The $S$. aureus counts in the endogenous starter samples were considerably lower than those in the cheese samples. The values ranged from $<1$ to $3.11 \log$ cfu. $\mathrm{mL}^{-1}$ during the rainy season and from $<1$ to $2.76 \log$ cfu. $\mathrm{mL}^{-1}$ during the dry season (Table 2). These results also showed no statistical difference $(\mathrm{P}<0.05)$.

In the detection of staphylococcal enterotoxins in the cheese samples, only the SEA was found when the OSP method was used. Of all cheese samples analyzed ( 8 from each season), $75 \%$ had SEA type with no apparent influence of the season on enterotoxin production (Table 2). However, via the ELFAVIDAS ${ }^{\circledast}$ Staph enterotoxin II method, no enterotoxins were detected in any of the analyzed cheese samples.

$S$. aureus strains were induced in vitro to produce enterotoxins and tested by OSP in order to detect SEA, SEB, SEC, and SED. Of the 44 strains of $S$. aureus, $12.5 \%$ were able to

Table 1. Oligonucleotides used in the PCR techniques for detection of enterotoxin-encoding genes in Staphylococcus sp.

\begin{tabular}{|c|c|c|c|}
\hline Oligonucleotides (5'- 3') & Target gene & Encoded enterotoxin & Amplified product \\
\hline $\begin{array}{l}\text { SEA1: ACG ATC AAT TTT TAC AGC } \\
\text { SEA2: TGC ATG TTT TCA GAG TTA ATC }\end{array}$ & sea & SEA & $544 \mathrm{pb}$ \\
\hline $\begin{array}{l}\text { SEB1: GAA TGA TAT TAA TTC GCA TC } \\
\text { SEB2: TCT TTG TCG TAA GAT AAA CTT C }\end{array}$ & seb & SEB & $416 \mathrm{pb}$ \\
\hline $\begin{array}{l}\text { SEC1: GAC ATA AAA GCT AGG AAT TT } \\
\text { SEC2: AAA TCG GAT TAA CAT TAT CCA }\end{array}$ & $\sec$ & SEC & $257 \mathrm{pb}$ \\
\hline $\begin{array}{l}\text { SED1: TTA CTA GTT TGG TAA TAT CTC CTT } \\
\text { SED2: CCA CCA TAA CAA TTA ATG C }\end{array}$ & sed & SED & $334 \mathrm{pb}$ \\
\hline $\begin{array}{l}\text { SEE1: ATA GAT AAA GTT AAA ACA AGC AA } \\
\text { SEE2: TAA CTT ACC GTG GAC CC }\end{array}$ & see & SEE & $170 \mathrm{pb}$ \\
\hline
\end{tabular}

Source: Rosec and Gigaud (2002). 
Table 2. Results of the S. aureus counts and enterotoxin detection in endogenous starter and Artisan Minas cheese samples from the Serra da Canastra collected during rainy and dry seasons.

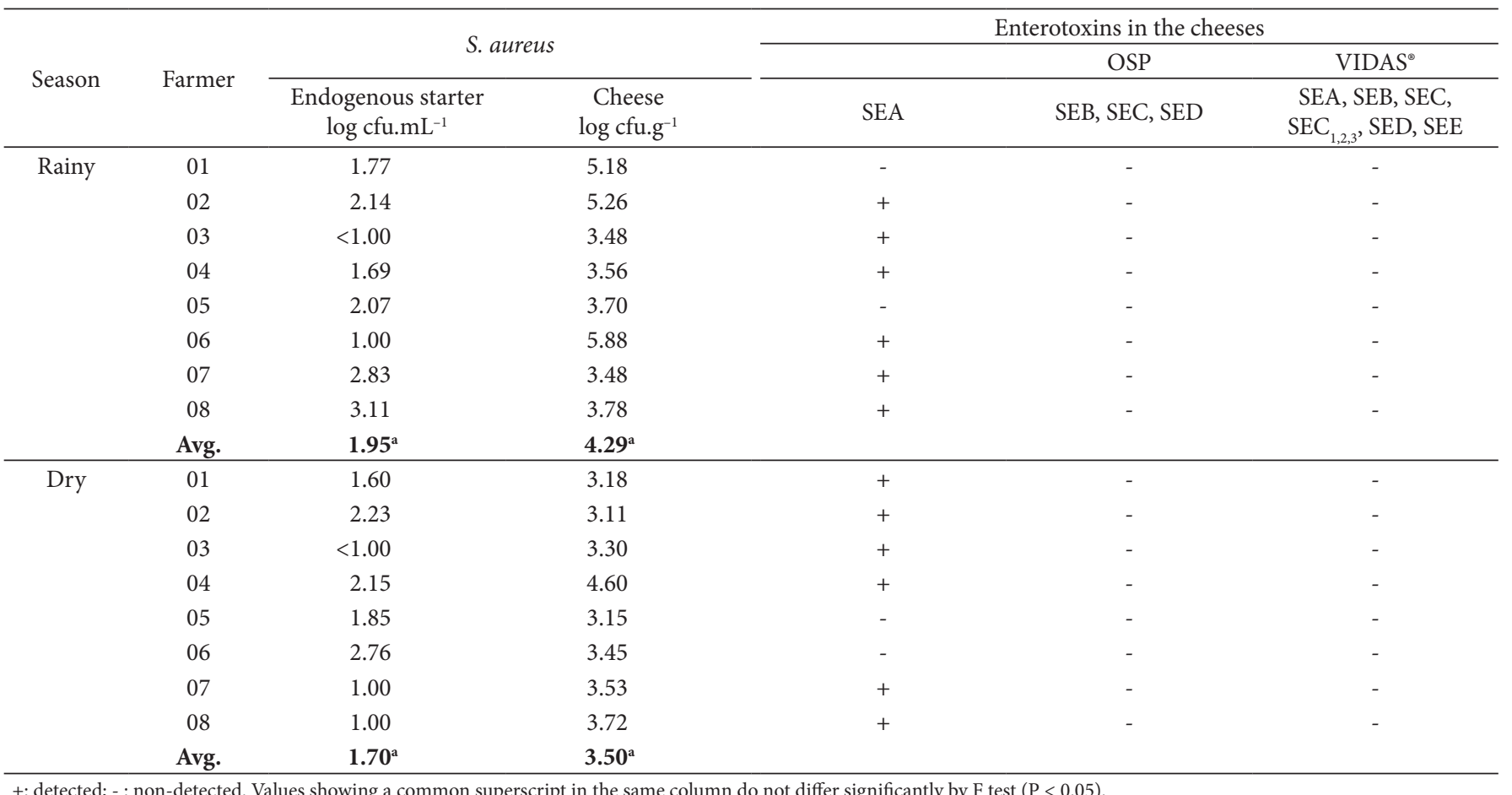

produce toxins, and SEA was the most prevalent gene among a larger number of isolates, followed by the SEC (data not shown).

The PCR analysis showed the presence of the seb gene in one isolate only (Figure 1). All other genes (sea, sec, sed, and see) where not detected in any isolate in this assay (data not shown).

\section{Discussion}

The average values of $S$. aureus counts found in Minas Artisan cheese samples, $4.29 \mathrm{log}$ cfu. $\mathrm{g}^{-1}$ during the rainy season and $3.50 \log$ cfu. $\mathrm{g}^{-1}$ during the dry season, were higher than those allowed by current Brazilian legislation $\left(2.0 \mathrm{log}\right.$ cfu. $\left.\mathrm{g}^{-1}\right)$. These counts may favor staphylococcal enterotoxin production under appropriate environmental conditions, especially considering that there are reports in which lower counts are involved in the production of staphylococcal enterotoxin in foods (OTERO et al., 1988; MEYRAND et al., 1998; BALABAN; RASOOLY, 2000). High counts of $S$. aureus have been frequently reported in Artisan cheeses, and they are usually associated with poor sanitary conditions during production, storage, and transportation (PINTO; MARTINS; FERREIRA, 2004; MARTINS, 2006; BORELLI et al., 2006; BRANT; FONSECA; SILVA, 2007). The low counts of $S$. aureus in the endogenous starter samples may be related to the dominant microbiota present, especially lactic acid bacteria, which may inhibit the growth of pathogenic microorganisms (NOBREGA; FERREIRA; DORES, 2008; BORELLI et al., 2006).

Staphylococcal enterotoxin A (SEA) is among the most frequently identified enterotoxins in food poisoning outbreaks (CARMO et al., 2004). The results obtained indicated the

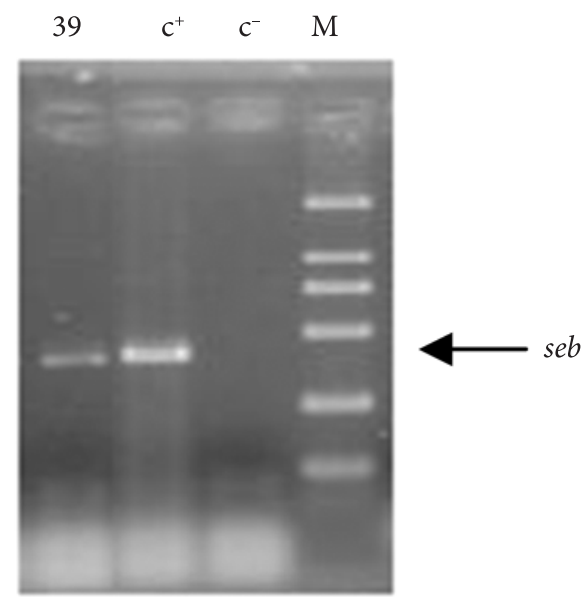

Figure 1. Agarose gel electrophoresis of PCR products amplified with the SEB1/SEB2 primers for the specific seb gene from the staphylococcal enterotoxin SEB. Column 39: positive isolate for the gene seb. Column $\mathrm{c}^{+}$: positive control gene seb (S. aureus ATCC 14458).Column c-: negative control from the reaction and column M: molecular weight marker (Amersham, 100pb).

presence of SEA in 75\% of the cheese samples and in $4.54 \%$ of the isolated strains when the OSP method was used. Unexpectedly, this enterotoxin was not detected by the ELFA-VIDAS method even though it is considered a more sensitive assay $(1 \mathrm{ng} / \mathrm{mL})$ (HENNEKINNE; DE BUYSER; DRAGACCI, 2011) then the OSP method (100 ng/mL) (DIAS et al., 2008). 
The Sea and sec genes could not be detected by the PCR analysis, even for the SEA and SEC-positive strains. Interestingly, controversial results were also found by Dias et al. (2008) when comparing the OSP and ELFA-VIDAS methods. They observed that among 91 food samples, $31.4 \%$ were positive for enterotoxin (OSP), but all of them were negative when tested by the ELFAVIDAS method.

According to Gilligan et al. (2000), techniques that use commercial diagnostic kits based on enzymatic immunoassay, as well as OSP and radioimmunoassays are widely used for the staphylococcal enterotoxin detection. However, sensitivity and specificity may vary depending on the purity of the reagents and the level of toxin expression. Aitichou et al. (2004) argue that the sensitivity limit combined with the possibility of cross-reactivity and interferences inherent to the analyzed matrix, such as alkaline phosphatase, (DIAS et al., 2008; HENNEKINNE; DE BUYSER; DRAGACCI, 2011) are the major disadvantages of immunoassays, emphasizing the need to develop new methods for toxin diagnosis.

The results of low rate of enterotoxin production by S. aureus isolated strains from Artisan Minas cheese. was similar to that of other studies on Artisan cheeses. For instance, among 12 pools of strains of Staphylococcus sp. isolated from Artisan curd cheese in the state of Ceará (Brazil), Lima et al. (2005) found only a small pool (8.33\%) of strains capable of producing staphylococcal enterotoxins. Similar results were found by Vernozy-Rozand et al. (1996), who showed that among 187 strains of Staphylococcus sp. isolated from milk, whey, and goat cheese only $5.9 \%$ were able to produce the SEE. On the other hand, there are contradicting reports such as those published by Cunha Neto, Silva and Stamford (2002), who isolated enterotoxigenic Staphylococcus in cheese curds and found that $100 \%$ of the strains were positive for staphylococcal enterotoxin, and by Holeckova et. al. (2002), who found that among 51 strains isolated from sheep's milk cheese produced in Slovakia, 39.2\% were able to produce enterotoxins.

With regards to the PCR assay, of the five genes searched, only seb was detected in one strain only, and again it was verified a lack of correlation with the OSP method, indicating that seb was not expressed or it was expressed below the detection limit of the OSP method. The frequency of enterotoxin genes in $S$. aureus isolated from foods is highly variable. There are reports with results ranging from 3.6 (ARCURI et al., 2004) to $100 \%$ (NAJERA-SANCHES et al., 2003). Vernozy-Rozand et al. (1996) observed low percentage (5.9\%) of enterotoxigenic Staphylococcus among 187 strains isolated from milk, whey, and goat cheese. Among the five genes evaluated, the presence of the see gene was detected and the production of SEE was found for 11 isolates only.

The lack of correlation between the results from biochemical and molecular assays have already been observed in the literature (McLAUCHLIN et al., 2000; ROSEC; GIGAUD, 2002; JØRGENSEN et al., 2005). Jørgensen et al. (2005) and Kérouanton et al. (2007) suggested the possibility of variations in the sequences of the analyzed genes, which could hinder the proper annealing of the primers in the PCR reaction. Analysis of DNA sequences could be a solution to reveal additional differences in the genes that would be present in the isolates. McLauchlin et al. (2000) considered that the degree of homology between the enterotoxins, especially the less studied non-classical ones, could generate cross-immune reactions and generate false-positive results.

Despite the fact that most isolates did not produce classical enterotoxins, high counts of $S$. aureus in the analyzed cheese samples are still of great concern since there is a risk of the presence of non-tested enterotoxins. These results emphasize the need for better hygienic practices throughout the production, processing, and marketing of dairy products. Further studies are necessary in order to develop analytical methods that do not interfere with the results and include classical enterotoxins and the new enterotoxins described.

\section{Acknowledgements}

This study was funded by the Fundação de Amparo à Pesquisa do Estado de Minas Gerais (FAPEMIG - processo ${ }^{\circ}$. CVZ396/06).

\section{References}

AITICHOU, M. et al. Detection the Staphylococcus aureus enterotoxin $\mathrm{A}$ and $\mathrm{B}$ genes with PCR-EIA and a hand-held electrochemical sensor. Molecular and Cellular Probes, v. 18, p. 373-377, 2004. http://dx.doi.org/10.1016/j.mcp.2004.06.002

ARCURI, E. F. et al. Avaliação do potencial enterotoxigênico de Staphylococcus aureus isolados de leite cru refrigerado pela detecção dos genes sea, seb, sec, e sed através da PCR. In: CONGRESSO BRASILEIRO DE QUALIDADE DO LEITE, 2004, Passo Fundo. Anais... Passo Fundo, 2004.

BALABAN, N.; RASOOLY, A. Staphylococcal enterotoxins. International Journal of Food Microbiology, v. 61, n. 1, p. 1-10, 2000. http://dx.doi.org/10.1016/S0168-1605(00)00377-9

BORELLI, B. M. et al. Enteroxigenic Staphylococcus spp. and other microbial contaminants during production of Canastra cheese, Brazil. Brazilian Journal of Microbiology, v. 37, p. 545-550, 2006. http://dx.doi.org/10.1590/S1517-83822006000400026

BRANT, L. M. F.; FONSECA, L. M.; SILVA, M. C. C. Avaliação da qualidade microbiológica do queijo-de-minas artesanal do SerroMG. Arquivo Brasileiro de Medicina Veterinária e Zootecnia, v. 59, n. 6, p. 1570-1574, 2007. http://dx.doi.org/10.1590/S010209352007000600033

CARMO, L. S. et al. A case study of a massive Staphylococcal food poisoning incidente. Foodborne Pathogens and Disease, v. 1, n. 4, p. 241-246, 2004. http://dx.doi.org/10.1089/fpd.2004.1.241

CUNHA NETO, A.; SILVA, C. G. M.; STAMFORD, T. L. M. Staphylococcus enterotoxigênicos em alimentos in natura e processados no estado de Pernanbuco, Brasil. Ciência e Tecnologia de Alimentos, v. 22, n. 3, p. 263-271, 2002. http://dx.doi. org/10.1590/S0101-20612002000300012

DE BUYSER, M. L. D. et al. Implication of milk and milk products in food-borne diseases in France and in different industrialized countries. International Journal of Food Microbiology, v. 67, n. 1, p. 1-17, 2001. http://dx.doi.org/10.1016/S0168-1605(01)00443-3

DIAS, R. S. et al. Detecção de enterotoxinas estafilocócicas e de linhagens enterotoxigênicas em alimentos envolvidos em surtos de toxinfecção alimentar. Revista da Fundação Ezequiel Dias, v. 3, n. 2, p. 37-44, 2008. 
DORES, M. T. Queijo Minas Artesanal da canastra maturado a temperatura ambiente e sob refrigeração. 2007. 130 f. Dissertação (Mestrado em Ciência de Alimentos)-Universidade Federal de Viçosa, Viçosa, 2007.

GILLIGAN, K. et al. Identification of Staphylococcus aureus enterotoxins $\mathrm{A}$ and $\mathrm{B}$ genes by PCR-ELISA. Molecular and Cellular Probes, v. 14, p. 71-78, 2000. http://dx.doi.org/10.1006/mcpr.2000.0286

HENNEKINNE, J.-A.; DE BUYSER, M.-L.; DRAGACCI, S. Staphylococcus aureus and its food poisoning toxins: characterization and outbreak investigation. FEMS Microbiology Reviews, v. 36, n. 4, p. 815-836, 2011. http://dx.doi.org/10.1111/j.15746976.2011.00311.x

HESSELBARTH, J.; SCHWARZ, S. Comparative ribotyping of Staphylococcus intermedius from dog, pigeons, horses and mink. Veterinay Microbiology, v. 45, p. 11-17, 1995. http://dx.doi. org/10.1016/0378-1135(94)00125-G

IKEDA, T. et al. Mass outbreak of food poisoning disease caused by small amounts of Staphylococcal enterotoxins A and H. Applied and Environmental Microbiology, v. 71, n. 5, p. 2793- 2795, 2005. http://dx.doi.org/10.1128/AEM.71.5.2793-2795.2005

JØRGENSEN, H. J. et al. An outbreak of staphylococcal food poisoning caused by enterotoxin $\mathrm{H}$ in mashed potato made with raw milk. FEMS Microbiology Letters, v. 252, p. 267-272, 2005. http://dx.doi. org/10.1016/j.femsle.2005.09.005

KÉROUANTON, A. et al. Characterization of Staphylococcus aureus strains associated with food poisoning outbreaks in France. International Journal of Food Microbiology, v. 115, p. 369-375, 2007. http://dx.doi.org/10.1016/j.ijfoodmicro.2006.10.050

LIMA, A. F. et al. Incidência de Staphylococcus sp. e Staphylococcus coagulase positiva. Revista do Instituto de Laticínios Cândido Tostes, v. 60, n. 345, p. 195-198, 2005.

MARTIN, S. E.; MYERS, E. R.; LANDOLO, J. J. Staphylococcus aureus. In: HUI, Y. H.; PIERSON, M. D.; GORHAM, J. R. (Eds.). Foodborn disease handbook: bacterial pathogens. New York: Marcel Dekker, 2001. p. 345-381.

MARTINS, J. M. Características físico-químicas e microbiológicas durante a maturação do queijo Minas Artesanal da região do Serro. 2006. 158 f. Tese (Doutorado em Ciência de Alimentos)Universidade Federal de Viçosa, Viçosa, 2006.

McLAUCHLIN, J. et al. The detection of enterotoxins and toxic shock syndrome toxin genes in Staphylococcus aureus by polymerase chain reaction. Journal of Food Protection, v. 63, p. 479-488, 2000.
MEYRAND, A. et al. Growth and enterotoxin production of Staphylococcus aureus during the manufacture and ripening of Camembert-type cheeses from raw goats' milk. Journal of Applied Microbiology, v. 85, p. 537-544, 1998. http://dx.doi.org/10.1046/ j.1365-2672.1998.853531.x

NAJERA-SANCHES, G. et al. Development of two multiplex plymerase Caín reactions for the detection of enterotoxigenic strains of Staphyloccus aureus isolated from foods. Journal of Food Protection, v. 66, n. 6, p. 1055-1062, 2003.

NOBREGA, J. E.; FERREIRA, C. L. L. F.; DORES, M. T. Diferenças sazonais no fermento endógeno utilizado na produção do queijo minas artesanal produzido na Serra da Canastra, Minas Gerais. Revista do Instituto de Laticínios Cândido Tostes, v. 63, p. 2630, 2008 .

OTERO, A. et al. Effect of a commercial starter culture on growth of Staphylococcus aureus and thermonuclease and enterotoxins (C1 and $\mathrm{C} 2$ ) production in broth cultures. Institute Journal Food Microbiology, v. 6, p. 107-114, 1988. http://dx.doi. org/10.1016/0168-1605(88)90047-5

PINTO, M. S.; MARTINS, J. M.; FERREIRA, C. L. L. F. Queijo Minas artesanal da Região do Serro: Avaliação de Staphylococcus aureus e suas enterotoxinas. Revista do Instituto de Laticínios Cândido Tostes, v. 59, n. 339, p. 336-338, 2004.

ROBBINS, R.; GOULD, S.; BERGDOLL, M. S. Detecting the enterotogenicity of Staphylococcus aureus strains. Applied Microbiology, v. 28, p. 946-950,1974.

ROSEC, J. P.; GIGAUD, O. Staphylococcal enterotoxin genes of classical and new types detected by PCR in France. International Journal of Food Microbiology, v. 77, p. 61-70, 2002. http://dx.doi.org/10.1016/ S0168-1605(02)00044-2

SEO, K. S.; BOHACH, G. A. Staphylococcal Food Poisoning. In: JUNEJA, V. K.; SOFOS, J. N. (Eds.). Pathogens and Toxins in Foods. Washington: ASM Press, 2010. p. 119-130.

STAMFORD, T. L. M. et al. Enterotoxigenicidade de Staphylococcus spp. Isolados de leite in natura. Ciência e Tecnologia de Alimentos, v. 30 , n. 1 , p. $41-45,2006$. http://dx.doi.org/10.1590/S010120612006000100007

VERNOZY-ROZAND, C. et al. Identification Micrococcaceae isolated from goat's milk and cheese in the Poitou-Charentes region. International Journal of Food Microbiology, v. 30, n. 3, p. 373-378, 1996. http://dx.doi.org/10.1016/0168-1605(96)00953-1

ZWEIFEL, C. et al. Determination of various microbiological parameters in raw milk and raw milk cheese produced by biofarms. Archiv für Lebensmittelhygiene, v. 57, p. 13-16, 2006. 